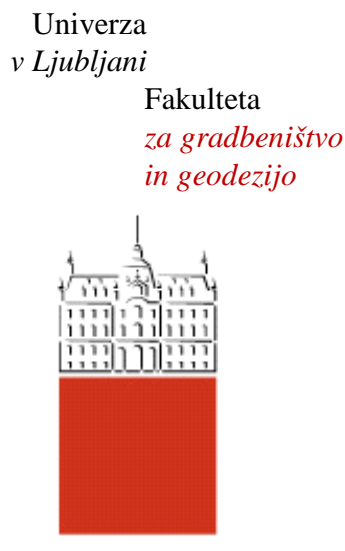

Jamova 2

1000 Ljubljana, Slovenija http://www3.fgg.uni-lj.si/

DRUGG - Digitalni repozitorij UL FGG http://drugg.fgg.uni-lj.si/

Ta članek je avtorjeva zadnja recenzirana različica, kot je bila sprejeta po opravljeni recenziji.

Prosimo, da se pri navajanju sklicujete na bibliografske podatke, kot je navedeno:
University

of Ljubljana

Faculty of

Civil and Geodetic

Engineering

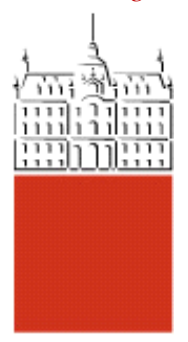

Jamova 2

SI - 1000 Ljubljana, Slovenia

http://www3.fgg.uni-lj.si/en/

DRUGG - The Digital Repository http://drugg.fgg.uni-lj.si/

This version of the article is author's manuscript as accepted for publishing after the review process.

When citing, please refer to the publisher's bibliographic information as follows:

Toratti, T., Schnabl, S. in Turk, G. 2007. Reliability analysis of a glulam beam. Structural Safety 29, 4: 279-293.

DOI: $10.1016 /$ j.strusafe.2006.07.011. 


\title{
Reliability analysis of a glulam beam
}

Dr. Tomi Toratti, VTT Finland

Simon Schnabl, University of Ljubljana, Slovenia

Prof. Goran Turk, University of Ljubljana, Slovenia

\begin{abstract}
The present case study is an example of the use of reliability analysis to asses the failure probability of a tapered glulam beam. This beam is part of a true structure built for a super market in the town of Kokemäki in Finland. The reliability analysis is carried out using the snow load statistics available from the site and on material strength information available from previous experiments. The Eurocode 5 and the Finnish building code are used as the deterministic methods to which the probabilistic method is compared to. The calculations show that the effect of the strength variation is not significant, when the coefficient of variation of the strength is around $15 \%$ as usually assumed for glulam. The probability of failure resulting from a deterministic design based on Eurocode 5 is low compared to the target values and lower sections are possible if applying a probabilistic design method. In fire design, if a 60 minute resistance is required, this is not the case according to Eurocode 5 design procedures, a higher section would be required. However, a probabilistic based fire analysis results in bounds for the yearly probability of failure which are comparable to the target value and to the values obtained from the normal probabilistic based design.
\end{abstract}

\section{Introduction}

The structure of the Kokemäki K-Market is analysed in this case study. This is a timber beamcolumn structure of glued laminated wood (glulam). Glulam columns support $17 \mathrm{~m}$ long beams which compose the roof structure (see Figure 1).
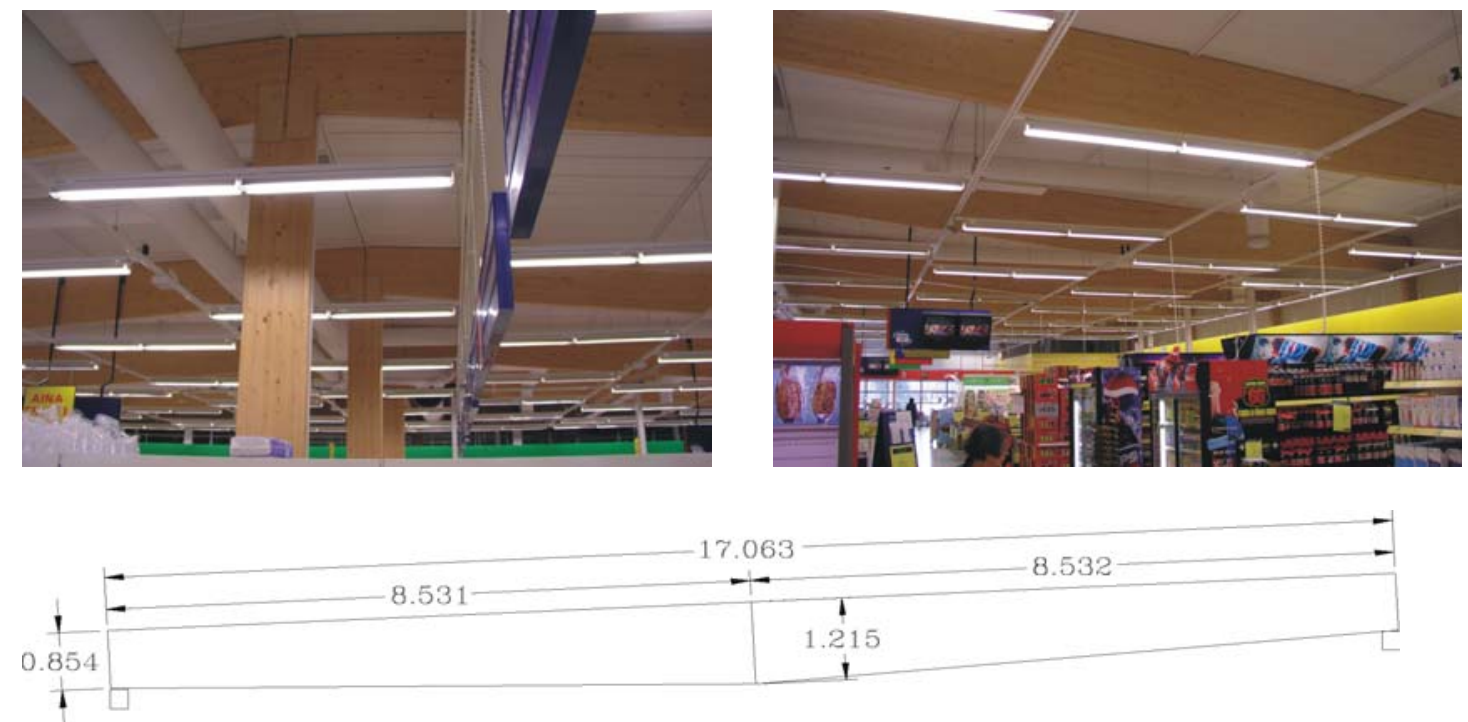

Figure 1. Kokemäki K-Market and the geometry of the tapered glulam beam analysed in this case study

The reliability analysis will be carried out on the main glulam beam, which is tapered from the bottom edge. The analysis will first be done in a normal design situation, during which also the sensitivity of the beam strength variation will be assessed. The reliability in a fire situation will also 
be carried out. Lateral torsional buckling of the beam was taken into account according to Eurocode 5 [4]. The calculated probabilities are for a one year reference period, unless otherwise stated.

\section{Statistical distributions of the variables}

For the present analysis, two main sources for input data are used. Namely, the probabilistic model code [6] and [10], which is a Nordic study on the calibration of partial safety factors for various building materials. Table 1 summarises the input recommended in [10]. Extensive reliability studies have also been carried out by Thelandersson et al. [12] and Ranta-Maunus et al. [9]. In RantaMaunus et al. [9] , the emphasis was on the precise description of the strength lower tail distribution for wooden products and on the calibration of partial safety factors for wooden structures. In Thelandersson et al. [12], the emphasis was on the long-term load analysis and related calibration of the strength modification factors.

Table 1. Statistical distributions and coefficients of variation recommended in [10]

\begin{tabular}{|c|c|c|c|c|c|c|}
\hline \multicolumn{2}{|c|}{ Type of parameter } & \multirow[t]{2}{*}{ Parameter } & \multicolumn{3}{|c|}{ Coefficient of variation } & \multirow{2}{*}{$\begin{array}{c}\text { Distribution } \\
\text { type }\end{array}$} \\
\hline & & & Concrete & Steel & Glulam & \\
\hline \multirow[t]{2}{*}{ Actions } & Permanent & $\begin{array}{l}\text { Self-weight } \\
\text { Other }\end{array}$ & $\begin{array}{l}0.06 \\
0.10\end{array}$ & $\begin{array}{l}0.02 \\
0.10\end{array}$ & $\begin{array}{l}0.06 \\
0.10\end{array}$ & $\begin{array}{l}\text { Normal } \\
\text { Normal }\end{array}$ \\
\hline & Variable & $\begin{array}{l}\text { Environmental } \\
\text { Imposed }\end{array}$ & $\begin{array}{l}0.40 \\
0.20\end{array}$ & $\begin{array}{l}0.40 \\
0.20\end{array}$ & $\begin{array}{l}0.40 \\
0.20\end{array}$ & $\begin{array}{l}\text { Gumbel } \\
\text { Gumbel }\end{array}$ \\
\hline \multicolumn{2}{|c|}{ Strength } & $\begin{array}{l}\text { Concrete } \\
\text { Reinforcement } \\
\text { Structural Steel } \\
\text { Glulam }\end{array}$ & $\begin{array}{l}0.10 \\
0.04\end{array}$ & 0.05 & 0.15 & $\begin{array}{l}\text { Log-Normal } \\
\text { Log-Normal } \\
\text { Log-Normal } \\
\text { Log-Normal }\end{array}$ \\
\hline \multicolumn{2}{|c|}{ Geometry } & $\begin{array}{l}\text { Effective depth } \\
\text { Beam depth } \\
\text { Beam width } \\
\text { Plate thickness }\end{array}$ & $\begin{array}{l}0.02 \\
0.02 \\
0.02\end{array}$ & $\begin{array}{l}0.01 \\
0.01 \\
0.04 \\
\end{array}$ & $\begin{array}{l}0.01 \\
0.01\end{array}$ & $\begin{array}{l}\text { Normal } \\
\text { Normal } \\
\text { Normal } \\
\text { Normal } \\
\end{array}$ \\
\hline \multicolumn{2}{|c|}{ Model uncertainties } & R-model & 0.05 & 0.05 & 0.05 & Normal \\
\hline
\end{tabular}

Some further background is given in the following to the distributions concerning the glulam material strength and snow loads.

\section{Glulam strength distribution}

There exists few test data which could be used to describe the glulam strength distribution. Much more is available for other wooden materials like structural timber, LVL or plywood. To obtain the lower tail strength distribution with enough accuracy, a high number of tests are required. The largest test sample available to the authors is summarised in Table 2. This data was obtained in a joint Nordic project on the reliability of timber. The tests were carried out in NTI Norway.

In these test samples, the target characteristic values were achieved. The tail fitting of the strength distribution resulted in a coefficient of variation of $13 \%$ and $19 \%$ when using the log-normal distribution. It was concluded in the above reference, that until further evidence, a log-normal distribution with a coefficient of variation of $15 \%$ may be recommended. More test results on glulam are however needed. 
Table 2. Available glulam test data [9]

\begin{tabular}{|l|c|c|l|c|c|l|c|}
\hline & $\begin{array}{c}\text { Target } f_{0.05} \\
{\left[\mathrm{~N} / \mathrm{mm}^{2}\right]}\end{array}$ & $\begin{array}{c}f_{0.05} \text { in test } \\
{\left[\mathrm{N} / \mathrm{mm}^{2}\right]}\end{array}$ & $\begin{array}{l}\text { Explanation of } \\
\text { test }\end{array}$ & $\begin{array}{c}\text { Sample } \\
\text { size }\end{array}$ & $\begin{array}{c}\text { Tail fitted } \\
{[\%]}\end{array}$ & Fitting distribution & $\begin{array}{c}\text { COV } \\
{[\%]}\end{array}$ \\
\hline Glulam & 30 & 33.5 & $\begin{array}{l}\text { Edgewise } \\
\text { bending }\end{array}$ & 126 & 10 & $\begin{array}{l}\text { Normal } \\
\text { Log-normal }\end{array}$ & $\begin{array}{l}11 \\
13\end{array}$ \\
\hline Glulam & 37 & 39.9 & $\begin{array}{l}\text { Edgewise } \\
\text { bending }\end{array}$ & 109 & 10 & $\begin{array}{l}\text { Normal } \\
\text { Log-normal }\end{array}$ & 14 \\
19
\end{tabular}

The snow load distribution

In reference [2] Perälä \& Reuna (1990), the snow load values for different locations in Finland are given for the period of 33 years. The example analysis here is done to a building in the city of Kokemäki and a measurement sight with closest location is chosen. The following figure shows the Gumbel plot of the yearly maximum snow loads (water equivalents). ISO CW 4355 [1] recommends using the extreme value distribution (Gumbel) for the annual maximum snow loads. The characteristic ground snow load $\mathrm{V}_{0.98}$ extrapolated from the figure is $220 \mathrm{~mm}$ (water equivalent). The characteristic ground snow loads in Eurocode 5 for the area give values of $2-2.5$ $\mathrm{kN} / \mathrm{m}^{2}$, which is in agreement with the measurements. The measured value is used in the proceeding analysis.

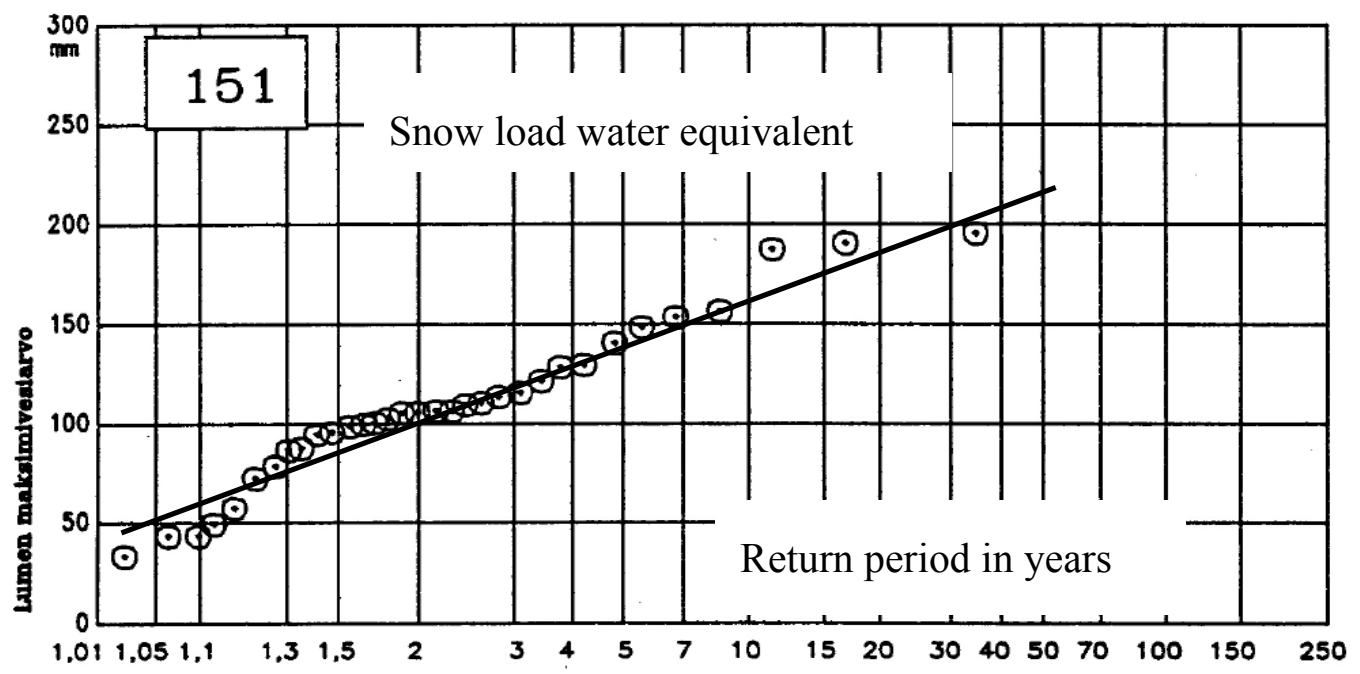

Figure 2. The measured ground snow load close to Kokemäki [2]

\section{Statistical distributions of the variables used in this study:}

In the present study, the distributions used for the loads and strengths are:

- Permanent load: normal $\left(V_{G}=0.05\right)$

- Snow load: Gumbel $\left(V_{Q}=0.40\right)$

- Glulam strength (bending and shear): $\log$-normal $\left(V_{F}=0.15\right)$

- Dimensions (height and width): normal $\left(V_{h \text { or } b}=0.01\right)$

- Model uncertainty: normal $\left(V_{m}=0.05\right.$ or 0.10$)$

\section{Load and strength parameters}

The dead load, $G$, is normally distributed. The glulam beam self-weight is assumed to be $0.88 \mathrm{kN} / \mathrm{m}$ acting on the beam as a line-load and the roof self-weight $0.44 \mathrm{kN} / \mathrm{m}^{2}$ acting on the whole roof area. Since the beams are $6.3 \mathrm{~m}$ apart the width of the roof loading lumped to each beam is $6.3 \mathrm{~m}$. It is assumed also that the coefficient of variation is $V_{G}=5 \%$. This is a slightly lower value than 
presented in Table 1 for glulam self-weight, but it is a value of the whole roof which is composed of different materials. This value has been widely used in previous reliability studies for self-weight of structures. Therefore, the values used in analysis are:

$$
m_{G}=6.3 \cdot 0.44+0.88=3.65 \mathrm{kN} / \mathrm{m} \quad \sigma_{G}=m_{G} V_{G}=0.18 \mathrm{kN} / \mathrm{m} .
$$

The snow load, $Q$, is distributed by Gumbel distribution. The $98^{\text {th }}$ percentile of the distributed load is $q^{\prime}=1.73 \mathrm{kN} / \mathrm{m}^{2}$ (characteristic ground snow load is $2.15 \mathrm{kN} / \mathrm{m}^{2}$ ).

The ground to roof snow load conversion factor has been assigned a constant value of 0.8 in most calculations of this example. A sensitivity study is however performed in one example where a stochastic normally distributed value with a COV of $10 \%$ and of $20 \%$ is considered for this factor.

Thus the $98^{\text {th }}$ percentile of the snow load $Q$ is $q=Q_{0.98}=6.3 \cdot 1.73=10.9 \mathrm{kN} / \mathrm{m}$. The coefficient of variation is assumed to be $V_{Q}=0.40$. The parameters $u$ and $\alpha$ of Gumbel distribution are determined from the following equations

$$
\begin{aligned}
& V_{Q}=\frac{\sigma_{Q}}{m_{Q}}=\frac{\pi}{\sqrt{6} \alpha} \frac{1}{u+\frac{\gamma}{\alpha}}=0.40, \\
& F_{Q}\left(Q_{0.98}\right)=F_{Q}(10.9)=0.98=\exp \left(-\exp \left(-\alpha\left(Q_{0.98}-u\right)\right)\right)=\exp (-\exp (-\alpha(10.9-u))),
\end{aligned}
$$

where $\gamma=0.577216$ is the Euler constant. These equations can easily be solved

$$
\begin{aligned}
& \alpha=\frac{1.28255+3.32472 V_{q}}{Q_{0.98} V_{q}}=0.5992, \\
& u=\frac{Q_{0.98}\left(1.11201-0.500462 V_{Q}\right)}{1.11201+2.88263 V_{Q}}=4.3879 .
\end{aligned}
$$

The bending strength is lognormally distributed. The glulam material is of structural quality L40, thus it is assumed that the characteristic value is $f_{k}=F_{0.05}=39 \mathrm{~N} / \mathrm{mm}^{2}$ (short term strength). The coefficient of variation $V_{F}$ is assumed as 0.15 , except in the first analysis, where the parameter is varied from 0.05 to 0.40 . The parameters of the lognormal distributions $\widetilde{m}_{F}$ and $\sigma_{\ln F}$ are evaluated from the following equations:

$$
\begin{aligned}
& \sigma_{\ln F}^{2}=\ln \left(V_{F}^{2}+1\right), \\
& F_{F}\left(F_{0.05}\right)=F_{F}(39)=F_{U}\left(\frac{\ln F_{0.05}-\ln \widetilde{m}_{F}}{\sigma_{\ln F}}\right),
\end{aligned}
$$

where $F_{U}($.$) denotes cumulative distribution function of the standardised normal distribution. Thus,$ the relation between the parameters and characteristic value and coefficient of variation is given as follows:

$$
\begin{aligned}
& \sigma_{\ln F}=\sqrt{\ln \left(V_{F}^{2}+1\right)}, \\
& \tilde{m}_{F}=F_{0.05} \exp \left(-\sigma_{\ln F} F_{U}^{-1}(0.05)\right),
\end{aligned}
$$

where $F_{U}^{-1}($.$) is the inverse of the cumulative distribution function of the standardised normal$ distribution. Sometimes it is more convenient to describe the random variable by its moments 
instead of the distribution parameters. In the case of lognormal distribution the relations between the parameters and moments are

$$
\begin{aligned}
& m_{F}=\tilde{m}_{F} \exp \left(\frac{\sigma_{\ln F}^{2}}{2}\right), \\
& \sigma_{F}^{2}=m_{F}^{2}\left(\exp \left(\sigma_{\ln F}^{2}\right)-1\right) .
\end{aligned}
$$

The strength is reduced by the modification factor $k_{\text {mod }}$, which takes into account the effect of the duration of the load and the moisture content in the structure on strength parameters. The cross section dimensions are assumed normally distributed, with a coefficient of variation of $1 \%$.

\section{Mechanical analysis}

Since the beam is simply supported, the evaluation of internal forces is elementary. The structural analysis was carried out on bending at the critical cross section, bending at the apex section and shear. The initial analysis showed that the critical cross section is situated where the bending stresses are the highest. The beam height at this point is $1060 \mathrm{~mm}$. Bending at the apex zone is not critical. Also the shear capacity resulted in much lower probabilities of failure. Therefore in the following, only the critical cross section in bending is analysed. The strength reducing factor for torsional buckling is not required for normal design, but it becomes necessary for the fire design where more slender sections are analysed. Thus the strength reducing parameter $k_{\text {crit }}$ is omitted from the design equations (1-4) for the normal design situation. In the fire design situation, this parameter is included.

The stresses in the critical cross section are calculated in two different ways:

a) according to the Finnish building code on the design of timber structures B10 [7] and

b) according to Eurocode 5 [4].

The difference between the calculation methods of the glulam beam between these codes is the following:

a) According to B10, the normal stress $\sigma_{x x}$ should not exceed the bending strength $F$ taking into consideration a height effect in the critical cross section:

$$
\sigma_{x x} \leq C_{F} F, \quad C_{F}=\left(\frac{300}{h}\right)^{\frac{1}{9}}
$$

where $h$ is $1060 \mathrm{~mm}$. Thus, the value of $C_{F}$ is 0.87 . The design equation according to B10 is then:

$$
\frac{F}{\gamma_{\mathrm{m}}} k_{\mathrm{mod}} C_{F}>\left(\frac{N_{x p}(1.2 G+1.6 Q)}{b h}+\frac{6 M_{y p}(1.2 G+1.6 Q)}{b h^{2}}\right),
$$

where $\gamma_{\mathrm{m}}=1.3$ is the material partial safety factor, $k_{\mathrm{mod}}=1.0$ is the strength modification factor for load duration and moisture conditions, $C_{F}=0.87$ is the height effect factor and the dead and snow loads have been multiplied by the respective load safety factors.

b) According to Eurocode 5, the normal stress $\sigma_{x x}$ should not exceed the bending strength $F$ at the outermost fibre of the tapered edge: 


$$
\sigma_{x x} \leq k_{m, \alpha} F, \quad k_{m, \alpha}=\frac{1}{\sqrt{1+\left(\frac{f_{m, k}}{1.5 f_{v, k}} \tan \alpha\right)^{2}+\left(\frac{f_{m, k}}{f_{c, 90, k}} \tan ^{2} \alpha\right)^{2}}} .
$$

The angle between the beam main axis and the fibre direction deviate in the compressive side of the beam. In this case, the strength is reduced by the factor $k_{m, \alpha}$, which takes into account the influence of the taper in the compression side. $f_{m, k}, f_{v, k}, f_{c, 90, k}$, and $\alpha$ are the characteristic values of the bending strength, the shear strength, the compression strength perpendicular to the grain, and the angle of taper, respectively. The following values were taken (short-term characteristic strengths):

$f_{m, k}=39.0 \mathrm{~N} / \mathrm{mm}^{2}, f_{v, k}=3.5 \mathrm{~N} / \mathrm{mm}^{2}, f_{c, 90, k}=6 \mathrm{~N} / \mathrm{mm}^{2}$, and $\alpha=2.5^{\circ}$, these values result in $k_{m, \alpha}=$ 0.95. The design equation according to Eurocode 5 is then:

$$
\frac{F}{\gamma_{\mathrm{m}}} k_{\text {mod }} k_{m, \alpha}>\left(\frac{N_{x p}(1.2 G+1.5 Q)}{b h}+\frac{6 M_{y p}(1.2 G+1.5 Q)}{b h^{2}}\right)
$$

where $\gamma_{\mathrm{m}}=1.3$ is the material partial safety factor, $k_{\mathrm{mod}}=1.0$ is the strength modification factor for load duration and moisture conditions, $k_{m, \alpha}=0.95$ is the reduction factor described above and the dead and snow loads have been multiplied by the respective load safety factors.

\section{Reliability analysis for normal design}

\subsection{Reliability analysis using Gumbel distribution for yearly snow load}

The reliability analysis was performed by the computer program Comrel [11]. Initially, different reliability methods were tried. Since the problem is relatively simple, different methods (FORM, SORM, crude Monte Carlo, adaptive sampling, etc.) gave almost identical results. In adaptive sampling 20000 repetitions of the calculation were performed, whereas the number of simulations in crude Monte Carlo was 5000 000. There were clearly advantages with the other methods compared to crude Monte Carlo simulations: the solutions were more stable and the calculation was faster. In the following, the adaptive sampling procedure is used in the reliability analysis.

The limit state equation for the maximum bending stress case is:

$$
g=F k_{\text {mod }} \stackrel{k_{m, \alpha}}{\text { or }}-\left(\frac{N_{x p}(G+Q)}{b h}+\frac{6 M_{y p}(G+Q)}{b h^{2}}\right) k_{\text {model }}
$$

with variables:

- $\quad G$ : Permanent load (normal, $V_{G}=0.05$ )

- $Q$ : Snow Load (Gumbel, $C_{Q}=0.40$ )

- $\quad F$ : Glulam strength (log-normal, $V_{f}=0.15$ )

- $\quad b$ and $h$ : Section dimensions, height and width (normal, $V_{b \text { or } h}=0.01$ )

- $\quad k_{\text {model }}$ : Model uncertainty (normal, mean $=1.0, V_{m}=0.05$ or 0.10 )

and constants: 
$k_{\text {mod }}=1 / 1.3(\mathrm{~B} 10)$ or $0.8($ Eurocode 5$), C_{F}=0.87(\mathrm{~B} 10)$ or $k_{m, \alpha}=0.95$ (Eurocode 5), $N_{x p}=0.346$ $[\mathrm{kN}$ per unit load $\mathrm{kN} / \mathrm{m}]$ and $M_{y p}=29.144[\mathrm{kNm}$ per unit load $\mathrm{kN} / \mathrm{m}]\left(N_{x p}\right.$ and $M_{y p}$ are obtained by the mechanical analysis).

The probability of failure for the two different design codes as a function of the coefficient of variation of strength is shown in Fig. 3. The relationship is not monotonic; instead it has a maximum between 0.125 and 0.15 . The failure probability increases for larger or smaller coefficients of variation. From Fig. 3 we may notice that the probability of failure increases over 10 -fold as the coefficient of variation increases from 0.15 to 0.40 .

The probability of failure $P_{f}$ is close to a minimum at a strength variation of about $15 \%$, a value usually assumed for glulam, and it is not very sensitive to the strength variation in this range. Considering the failure probability, there seems to be no reason for attempting to decrease the strength variation, unless the material strength characteristic value is affected. This low sensitivity of the strength variation is also an advantage considering the accuracy of a reliability analysis of a glulam structure, since the variation of strength is not precisely known.

The sensitivity analysis also shows that there is some effect on increasing the model uncertainty parameter COV to $10 \%$ and a very similar effect on treating the ground to roof snow load conversion factor as a normally distributed random parameter with a COV of $10 \%$. These effects are however small. The effect is high for the case of COV of $20 \%$ on the ground to roof snow load factor, comparable to the difference in the $\beta$-value that results when using the two standards.

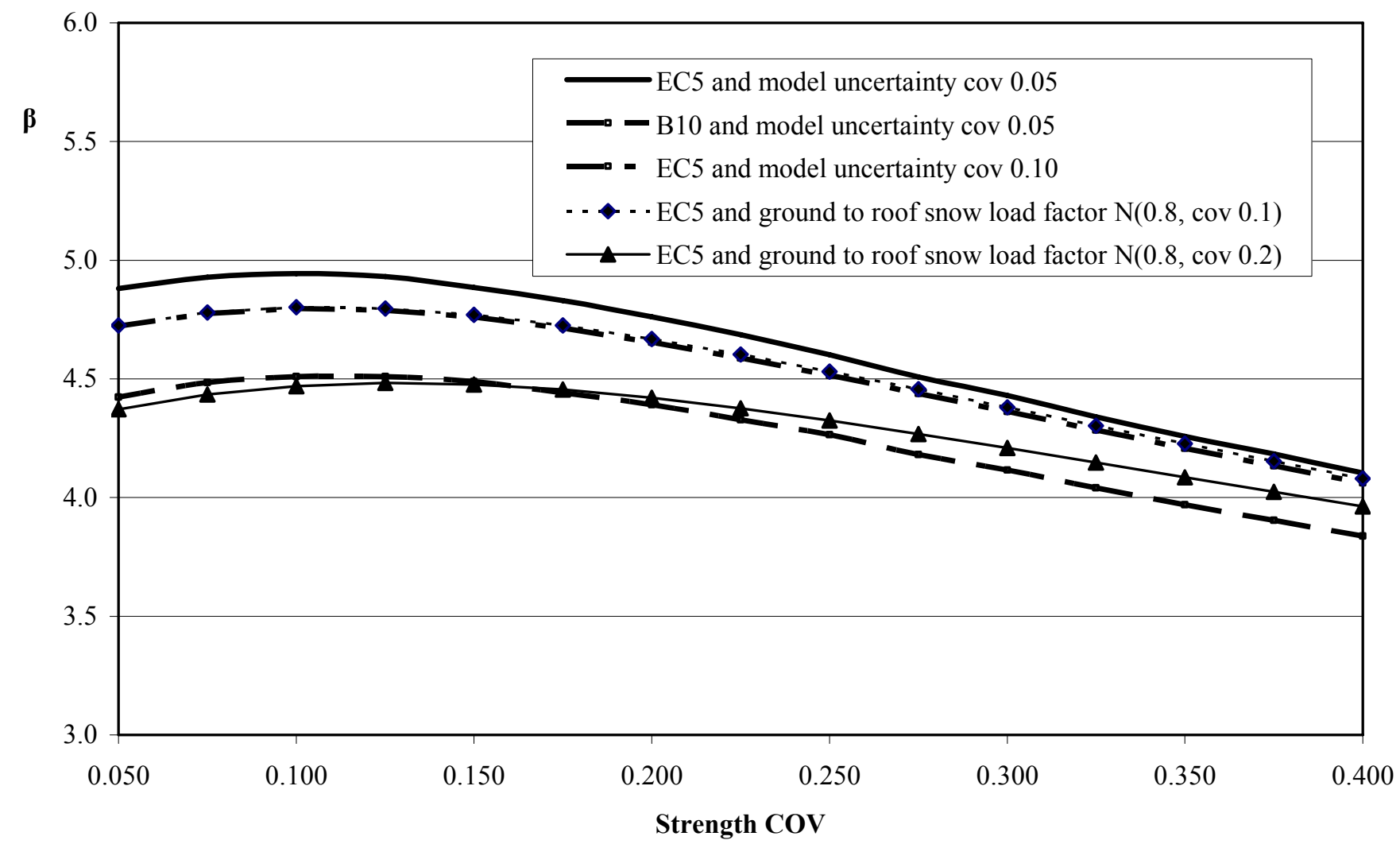

Figure 3. Reliability index $\beta$ as a function of strength coefficient of variation $V_{F}$. The comparison between EC5 and B10, the influence of model uncertainty COV (0.05 and 0.10), and the influence 
of random ground to roof snow load factor (COV 0.10 and 0.20$)$.

The calculation shows that for a glulam having a strength $\mathrm{COV}$ of $15 \%$, according to $\mathrm{B} 10$ the $\beta$ value is 4.49 corresponding to a failure probability of $P_{f}=3.56 \times 10^{-6}$ and according to EC5 the $\beta$ value is 4.89 corresponding to a failure probability of $P_{f}=0.51 \times 10^{-6}$. In all the following calculations the glulam strength coefficient of variation is $15 \%$, the model uncertainty coefficient of variation is $5 \%$ and the ground to roof snow load factor is treated as a constant deterministic parameter.

\subsection{Reliability of the beam at different months of a year}

In the following, the monthly measured snow load water equivalents were used in the analysis. This was done in order to see the variation of the reliability during a year and to compare the yearly maximum value with the code format calculated in the preceding chapter. The monthly snow loads were evaluated for a given day of every month using data of 33 years during the period between 1960 and 1993. These monthly snow load values were analysed and found to be normally distributed (personal communication [14]). The ground snow loads were transformed to roof loads using the conversion factor of 0.8 .

Table 3. Snow loads from location 35312 [2] modelled as normal distributions

\begin{tabular}{|l|c|c|c|c|}
\hline Month & Snow load water equivalent [mm] & \multicolumn{2}{c|}{ Snow load on the beam [kN/m] } \\
\hline & Mean & Standard deviation & Mean & Standard deviation \\
\hline January & 41.6 & 24.9 & 2.06 & 1.23 \\
\hline February & 67.5 & 30.3 & 3.34 & 1.50 \\
\hline March & 79.9 & 35.9 & 3.95 & 1.78 \\
\hline April & 41.0 & 36.9 & 2.03 & 1.82 \\
\hline May & 0 & - & 0 & - \\
\hline June & 0 & - & 0 & - \\
\hline July & 0 & - & 0 & - \\
\hline August & 0 & - & 0 & - \\
\hline September & 0 & - & 0 & - \\
\hline October & 0 & - & 0 & - \\
\hline November & 0 & - & 0.93 & 0.73 \\
\hline December & 18.7 & 14.8 & 0 & - \\
\hline
\end{tabular}




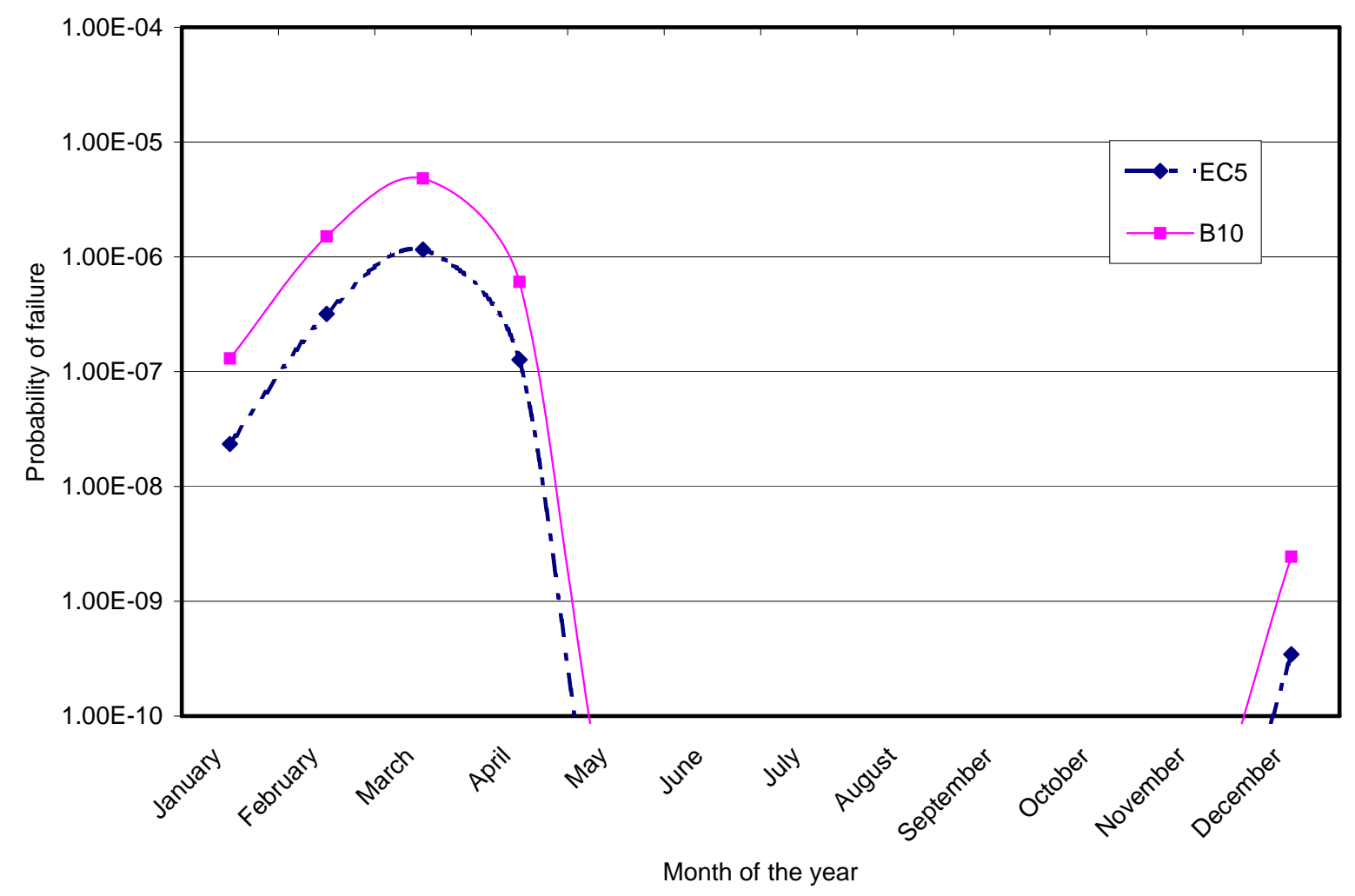

Figure 4. Probability of failure during one year (bending failure mode at maximum bending stress location)

The maximum probability of failure occurs during March in this case and the value is $P_{f}=1.16 \times$ $10^{-6}$ according to EC5 and $P_{f}=4.80 \times 10^{-6}$ according to B10. The simple bounds for yearly probability of failure are determined by:

$$
\begin{aligned}
& \max \left(P_{f, \text { january }}, P_{f, \text { february }}, \ldots, P_{f, \text { december }}\right) \leq P_{f, \text { year }} \leq \\
& \quad \leq 1-\left(1-P_{f, \text { january }}\right)\left(1-P_{f, \text { february }}\right) \cdots\left(1-P_{f, \text { december }}\right) .
\end{aligned}
$$

As may be observed from the Table 4, there is noticeable effect of the distribution model used for the snow load on the probability of failure. The differences are not high when the $\beta$-values are compared. The monthly normal distribution method gave a double failure probability, in the case of $\mathrm{B} 10$, and triple, in the case of EC5.

Table 4. Probability of failure during a year, the comparison between the values obtained using the yearly Gumbel distribution and the monthly normal distributions for the snow load.

\begin{tabular}{|c|c|c|c|}
\hline $\begin{array}{c}\text { Code } \\
\text { used }\end{array}$ & $\begin{array}{c}\beta \text {-value and } P_{f \text { year }} \\
\text { from fig. 3 based on yearly maximum Gumbel } \\
\text { distributed snow load }\end{array}$ & $\begin{array}{r}\text { Bounds for } \beta \text {-value and } P_{f, \text { year }} \\
\text { from eq. (4), based on normally distributed } \\
\text { monthly snow loads }\end{array}$ \\
\hline EC5 & $4.885\left(5.18 \times 10^{-7}\right)$ & $4.654\left(1.63 \times 10^{-6}\right)$ & $4.724\left(1.16 \times 10^{-6}\right)$ \\
\hline B10 & $4.489\left(3.58 \times 10^{-6}\right)$ & $4.344\left(7.05 \times 10^{-6}\right)$ & $4.426\left(4.80 \times 10^{-6}\right)$ \\
\hline
\end{tabular}




\subsection{Comparison to target reliability values}

The calculated reliabilities may be compared to the target values given in Table 5 for reliability class 2 (moderate consequences of failure). The probabilistic model code gives a value of 4.2, and prEN 1990 [3] gives a $\beta$-value of 4.7 . The calculated reliabilities are higher than the target levels given in the probabilistic model code [6].

Table 5. Recommended target $\beta$-values in ultimate limit state for a one year period according to the probabilistic model code[6] and prEN 1990[3].

\begin{tabular}{|c|c|c|c|c|c|c|c|}
\hline \multirow{3}{*}{\multicolumn{2}{|c|}{$\begin{array}{l}\text { Relative cost of } \\
\text { safety measure }\end{array}$}} & \multirow{2}{*}{\multicolumn{2}{|c|}{$\begin{array}{c}\text { Class } 1 \\
\begin{array}{c}\text { Minor consequences of } \\
\text { failure }\end{array}\end{array}$}} & \multirow{2}{*}{\multicolumn{2}{|c|}{$\begin{array}{l}\text { Class } 2 \\
\text { ate consequences } \\
\text { of failure }\end{array}$}} & \multirow{2}{*}{\multicolumn{2}{|c|}{$\begin{array}{c}\text { Class } 3 \\
\text { Large consequences or } \\
\text { failure }\end{array}$}} \\
\hline & & & & & & & \\
\hline & & $\beta$ & $P P_{f}$ & $\beta$ & $P_{f}$ & $\beta$ & $P_{f}$ \\
\hline \multirow{3}{*}{$\begin{array}{l}\text { Probab. } \\
\text { model } \\
\text { code }\end{array}$} & Large (A) & 3.1 & $\approx 9.7 \times 10^{-4}$ & 3.3 & $\approx 4.8 \times 10^{-4}$ & 3.7 & $\approx 1.1 \times 10^{-4}$ \\
\hline & Normal (B) & 3.7 & $\approx 1.1 \times 10^{-4}$ & 4.2 & $\approx 1.3 \times 10^{-5}$ & 4.4 & $\approx 5.4 \times 10^{-6}$ \\
\hline & Small (C) & 4.2 & $\approx 1.3 \times 10^{-5}$ & 4.4 & $\approx 5.4 \times 10^{-6}$ & 4.7 & $\approx 1.3 \times 10^{-6}$ \\
\hline $\begin{array}{l}\text { prEN } \\
1990\end{array}$ & & 4.2 & $\approx 1.3 \times 10^{-5}$ & 4.7 & $\approx 1.3 \times 10^{-6}$ & 5.2 & $\approx 10^{-7}$ \\
\hline
\end{tabular}

Dimensioning this beam using the deterministic design code method results in a $\beta$-value of 4.5 using the B10 code and in a $\beta$-value of 4.9 using the EC5 code design procedures (for yearly snow load the maximum gumbel distribution is used). These values are rather close to the target values. However, it would be possible to reduce the section height especially in the case of EC5, if the target reliabilities defined above are applied instead.

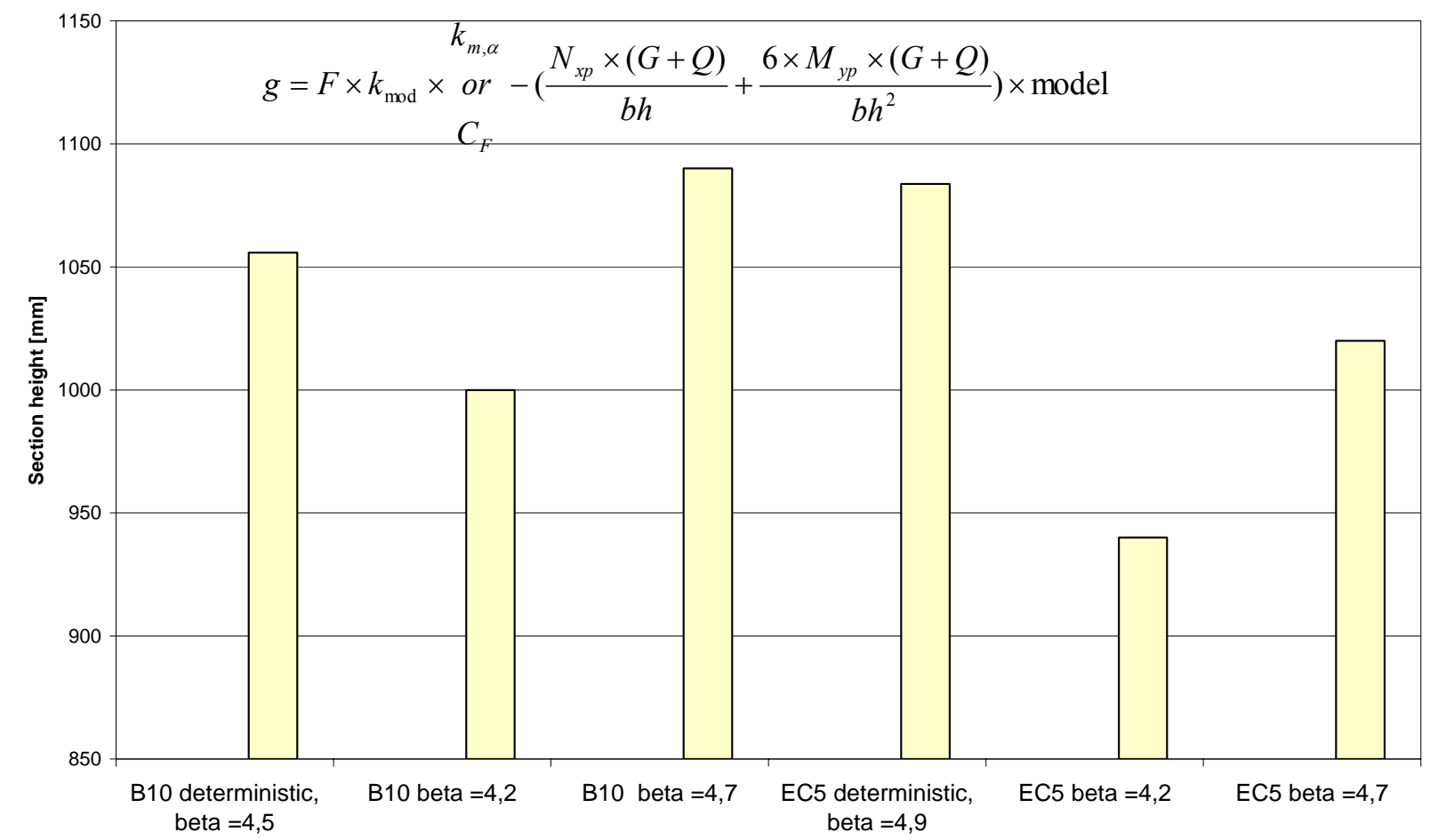

Figure 5. Required beam section heights based on design codes B10 (Finnish timber design code) eq. 2 and EC5 (Eurocode 5) eq. 4. The $\beta$-values resulting from a deterministic dimensioning, based 
on these design codes, are also given. If target $\beta$-values of Table 6 are applied, the required heights are shown.

\section{Reliability analysis of the beam under a fire situation}

In the following, several reliability analyses are carried out for the same beam under a fire condition. The analyses are done based on the methods given in prEN 1995-1-2 [5] on loading conditions under fire and on the charring rate of the wood section. Based on the previous example, only the most critical section is analysed for bending stresses, since this will be the determining section also in a fire condition. It is here assumed that the secondary structure spaced to $2.4 \mathrm{~m}$ on the top of the beam will be functional during the fire duration and this will support the top edge of the beam from buckling at these points.

\subsection{Failure probability in fire condition based on different month of the year}

In the first analysis, the charring rate is regarded as deterministic with the fixed value given in the design codes. Both design codes EC5 and B10 are compared in this analysis. The limit state equation for the maximum bending stress in a fire condition case is:

$$
g=F k_{c r i t} k_{\text {mod }, f i} \quad \begin{gathered}
k_{m, \alpha} \\
C_{F}
\end{gathered}-\left(\frac{N_{x p}(G+Q)}{b_{\text {red }} h_{\text {red }}}+\frac{6 M_{y p}(G+Q)}{b_{\text {red }} h_{\text {red }}^{2}}\right) k_{\text {model }}
$$

with variables:

- $\quad G$ : Permanent load (normal, $V_{G}=0.05$ ),

- $\quad Q$ : Snow load (as given in Table 3 for the different months);

- $\quad F$ : Glulam strength (log-normal, $V_{f}=0.15$ );

- $k_{c r i t}$ is the strength reduction factor for torsional buckling of the beam (as given in EC5), considering it is supported at $2.4 \mathrm{~m}$ spacing from the top edge. This had no effect in normal design, but in fire design with reduced cross sections this becomes highly significant.

- $\quad b_{\text {red }}$ and $h_{\text {red }}$ : Reduced section dimensions for height and width depending on fire exposure (normal, $V_{b}$ or $h=0.01$ ) using a charring rate,

EC5: $d_{e f}=\beta_{n} t+K_{o} d_{o}\left(\right.$ with $\beta_{\mathrm{n}}=0.7 \mathrm{~mm} / \mathrm{min}, K_{o}=1$ and $d_{o}=7 \mathrm{~mm}$ ), B10: $d_{e f}=\beta_{n} t$ (with $\left.\beta_{\mathrm{n}}=0.7 \mathrm{~mm} / \mathrm{min}\right)$;

- $\quad k_{\text {model }}$ : Model uncertainty (normal, mean $=1.0, V_{m}=0.05$ )

and constants

EC5: $k_{m o d, f i}=1.0, k_{m, \alpha}=0.95$ or

B10: $C_{F}=1(\mathrm{~B} 10)$,

$N_{x p}=0.346[\mathrm{kN}$ per unit load $(\mathrm{kN} / \mathrm{m})]$,

$M_{y p}=29.144[\mathrm{kNm}$ per unit load $(\mathrm{kN} / \mathrm{m})]\left(N_{x p}\right.$ and $M_{y p}$ result from the mechanical analysis). 


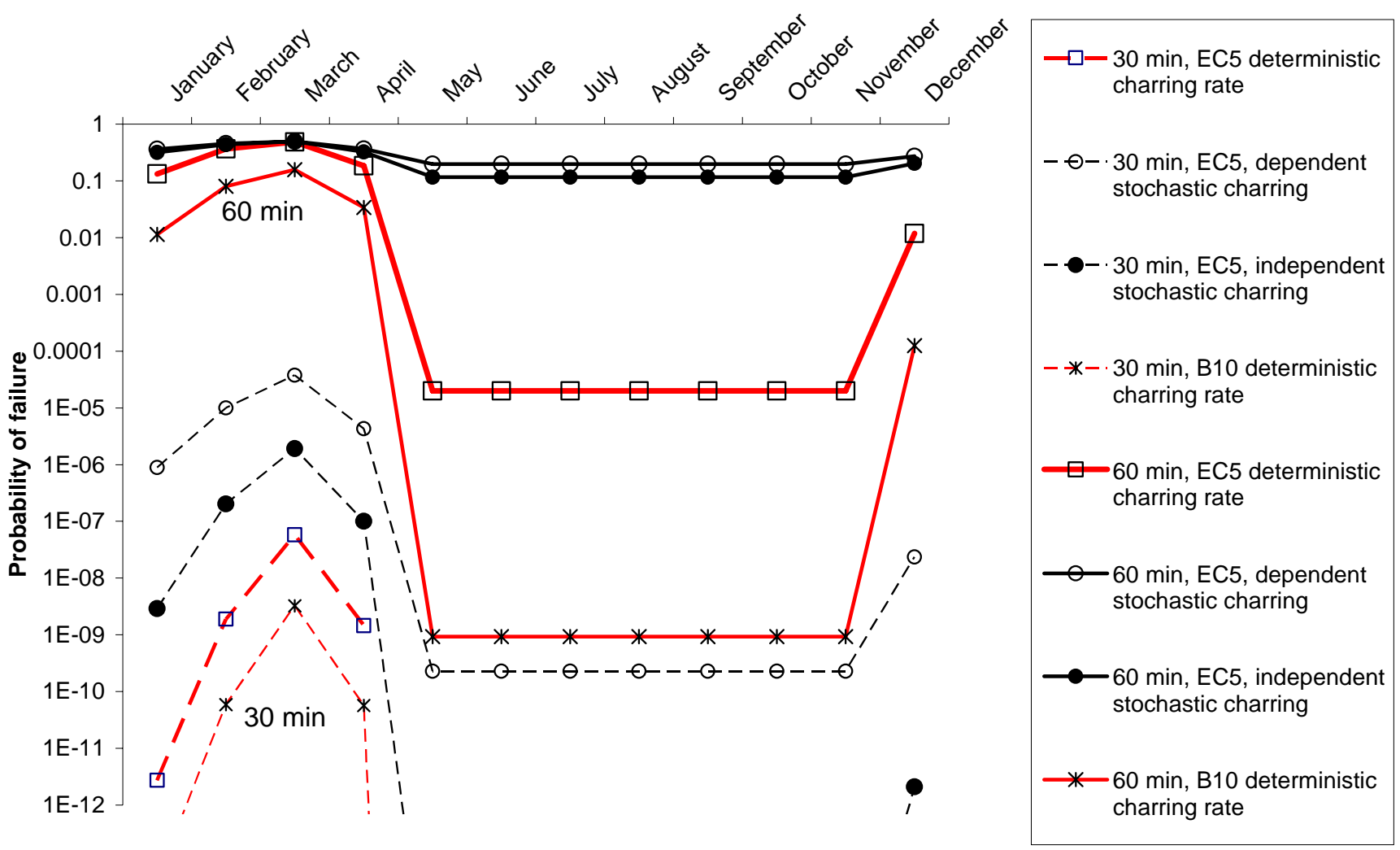

Figure 6. Results of the reliability analysis during a fire situation at different months of a year. This figure also includes results using stochastic charring $(\mathrm{COV}=0.2)$, which are calculated based on the following section.

The winter months have the highest probability of failure due to snow loads and March is most critical in this sense. The fire design according to EC5 is more conservative than according to B10.

\subsection{Failure probability considering a stochastic charring rate}

It has been observed from previous charring experiments that charring rates are variable between test pieces. Variabilities in the order of COV $=20 \%$ have been observed for glulam, but higher and lower variabilities have also been observed [14]. The limit state equation for the maximum bending stress in a fire condition in this case is:

$$
g=F k_{c r i t} k_{\text {mod, } f i} \quad \begin{aligned}
& k_{m, \alpha} \\
& C_{F}
\end{aligned}-\left(\frac{N_{x p}(G+Q)}{\left(b-d_{e f}^{\prime}-d_{e f}^{\prime \prime}\right)\left(h-d_{e f}^{\prime \prime \prime}\right)}+\frac{6 M_{y p}(G+Q)}{\left(b-d_{e f}^{\prime}-d_{e f}^{\prime \prime}\right)\left(h-d_{e f}^{\prime \prime \prime}\right)^{2}}\right) k_{\text {model }} .
$$

The variables are the same as in eq. (7), except here the charring rate is a normally distributed variable. The charring depths for the three different sides, $d_{e f}^{\prime}, d_{e f}^{\prime \prime}$ and $d_{e f}^{\prime \prime \prime}$ are normally distributed with a coefficient of variation of $0.1,0.2$ or 0.3 and with a mean value as given in the EC5 design code. These are also compared to a deterministic charring depth corresponding to the EC5 code value. The 3 different charring depths of the different sides of the beam, may or may not be independent, therefore two separate calculations were done, one assuming these are independent and the other dependent. 


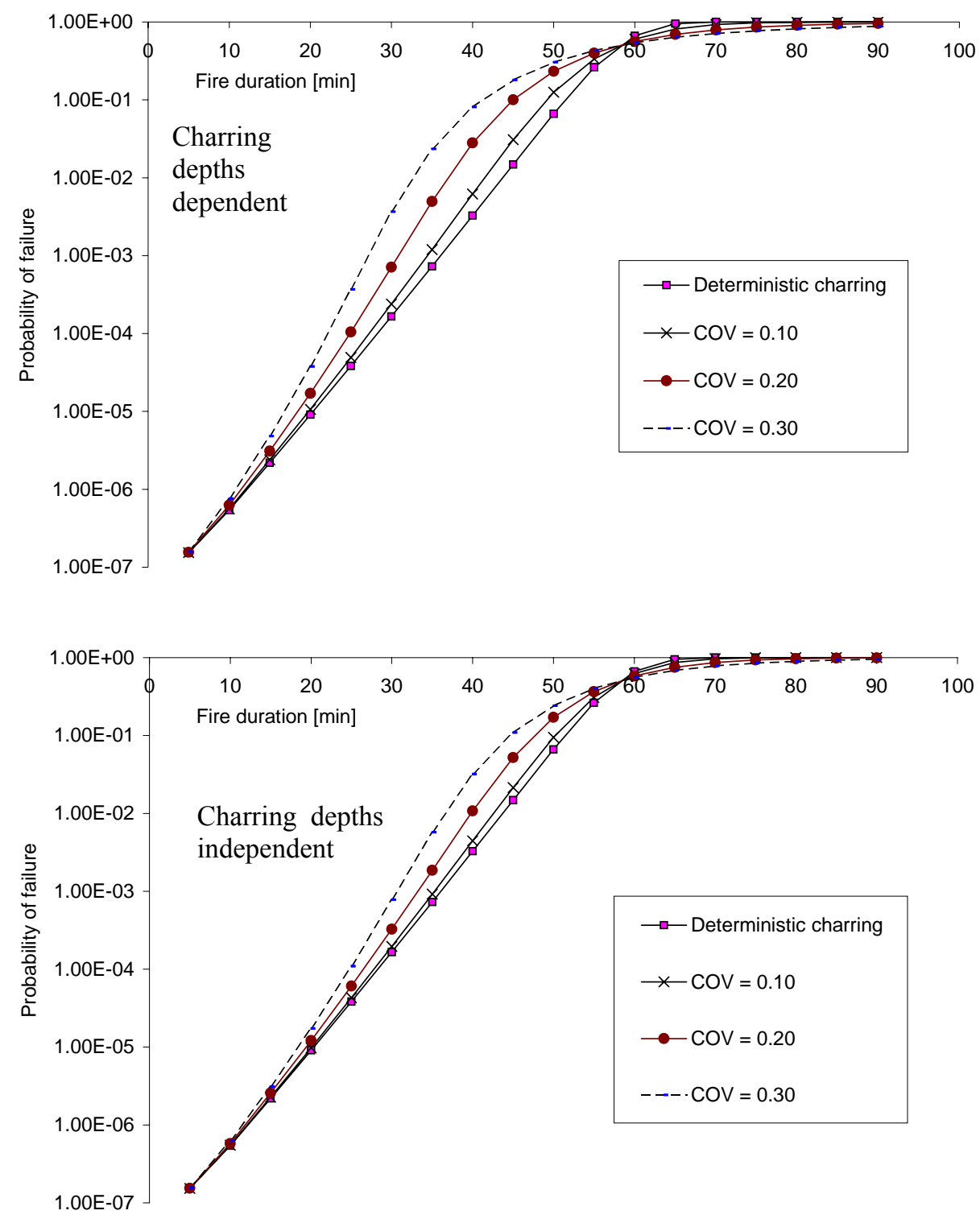

Figure 7. Effect of charring variability on the probability of failure.

Comparing the results obtained with the deterministic charring rate to the stochastic rate with a variability of $\mathrm{COV}=0.2$, the following may be observed. The effect of the charring rate being a stochastic variable is significant only after a fire duration of about 15 to 30 minutes, for shorter fire duration the failure probabilities are small and the differences negligible. At a fire duration approaching $60 \mathrm{~min}$, the effect of stochastic charring decreases again. This is true for high loads (Fig. 7), for low loads (Fig. 6 summer period) there is a high difference also at a 60 minute fire duration time. Also whether the charring rates between the sides are dependent or independent is of significance. This is a characteristic not well known, that is, whether the variability is more pronounced between different glulam beams (dependent or fully correlated) or within a glulam beam (independent or non-correlated). 
Table 6. Ratios of the failure probability between deterministic and stochastic $(\mathrm{COV}=0.2)$ charring rates at different fire duration times. (Yearly max. snow load Gumbel distributed).

\begin{tabular}{|l|c|c|c|c|}
\hline & $15 \mathrm{~min}$ & $30 \mathrm{~min}$ & $45 \mathrm{~min}$ & $60 \mathrm{~min}$ \\
\hline Deterministic & 1 & 1 & 1 & 1 \\
\hline Stochastic, independent & 1.2 & 2.0 & 3.5 & 0.9 \\
\hline Stochastic, dependent & 1.4 & 4.3 & 6.8 & 0.8 \\
\hline
\end{tabular}

\subsection{Failure probability of the beam during a 60 minute fire}

In the following calculations the following assumptions are taken: (1) the charring rate is taken deterministic as given in the codes, (2) the upper supporting structure is assumed to function during the fire in prevention of lateral buckling at the $2.4 \mathrm{~m}$ spacing points, (3) the snow load is modelled as monthly normal distribution, (4) failure is defined as structural failure, that is bending stresses exceeding the capacity.

Based on the probabilistic model code [6], the annual target probability of failure level is recommended as $P_{f \text { year }}=1.3 \times 10^{-5}$. Based on the probabilistic model code [6] the following probabilities for a dangerous fire scenario are given: $P_{i}$ (ignition) $=10^{-6} /$ year $/ \mathrm{m}^{2}$ or $0.083 \times 10^{-6} / \mathrm{month} / \mathrm{m}^{2}$ (value for shops/offices, area: $\left.1768 \mathrm{~m}^{2}\right), P_{f}$ (flashover|ignition) $=0.1$ (in the case of a public fire brigade).

Based on the above information, the bounds for yearly probability of failure of the structure can be calculated as:

$$
\begin{aligned}
& \max \left(P_{i} P_{f} P_{f, \text { fire, january }}, P_{i} P_{f} P_{f, \text { fire, february }}, \ldots, P_{i} P_{f} P_{f, \text { fire, december }}\right) \leq \\
& \quad \leq P_{f, \text { fire, year }} \leq \\
& \quad \leq 1-\left(\left(1-P_{i} P_{f} P_{f, \text { fire, january }}\right)\left(1-P_{i} P_{f} P_{f, \text { fire, february }}\right) \cdots\left(1-P_{i} P_{f} P_{f, \text { fire, december }}\right)\right) .
\end{aligned}
$$

\begin{tabular}{|c|c|c|c|c|c|c|c|c|}
\hline \multirow[b]{2}{*}{$P_{f, \text { fire, year }}$} & \multicolumn{6}{|c|}{ EC5 method } & \multirow{2}{*}{\multicolumn{2}{|c|}{$\begin{array}{c}\text { B10 method } \\
\text { Deterministic } \\
\text { charring }\end{array}$}} \\
\hline & \multicolumn{2}{|c|}{$\begin{array}{l}\text { Deterministic } \\
\text { charring }\end{array}$} & \multicolumn{2}{|c|}{$\begin{array}{c}\text { Stochastic dependent } \\
\text { charring }\end{array}$} & \multicolumn{2}{|c|}{$\begin{array}{c}\text { Stochastic } \\
\text { independent charring }\end{array}$} & & \\
\hline Fire duration $30 \mathrm{~min}$ & $8.55 \times 10^{-13}$ & $9.04 \times 10^{-1 .}$ & $5.52 \times 10^{-10}$ & $7.77 \times 10^{-10}$ & $2.82 \times 10^{-11}$ & $3.27 \times 10^{-11}$ & $4.81 \times 10^{-14}$ & $5.00 \times 10^{-14}$ \\
\hline Fire duration $60 \mathrm{~min}$ & $7.17 \times 10^{-6}$ & $1.74 \times 10^{-5}$ & $7.30 \times 10^{-6}$ & $4.91 \times 10^{-5}$ & $7.27 \times 10^{-6}$ & $3.82 \times 10^{-5}$ & $2.33 \times 10^{-6}$ & $4.18 \times 10^{-6}$ \\
\hline
\end{tabular}

The following results are obtained using the two different code methods:

Table 7. Bounds for the yearly probability of failure due to fire.

The yearly probability values above are comparable to the target level of the probabilistic model code.

Considering the limit state equation for fire, the $k_{\text {crit }}$ term, which reduces the strength due to lateral torsional buckling, becomes critical. This reduces the beam capacity at a fast rate as the charring progresses and the cross section becomes more slender. The fire design according to EC5 is conservative (compared to B10). Stochastic charring rates have an influence on the failure probabilities. 


\section{Summary}

In this case study, an example reliability analysis is carried out for a glued laminated beam. The analysis is done under normal loading conditions, considering the measured snow load during the period of 30 years and under a fire condition. The following conclusions can be drawn from the present analysis:

The coefficient of variation of the glued laminated timber is not very precisely known, its value is around $15 \%$ based on the available test results. Values of this order have also been used in earlier studies. Based on a sensitivity analysis, it seems that the reliability is not very sensitive for this parameter and thus for practical reasons it does not matter if this is not precisely known.

The probability of failure resulting from a deterministic design based on Eurocode 5 is low compared to the target values and smaller beam cross sections are possible if applying a probabilistic design method with the assigned target reliability.

If a 60 minute fire resistance is required, the deterministic fire design based on Eurocode 5 requires higher cross sections than normal design and it is determining. The fire design according to Eurocode 5 is more conservative than of the Finnish building codes due to differences in the charring rates and the modelling of lateral torsional buckling.

A probabilistic based fire analysis however results in bounds for the yearly probabilities of failure which indicate that the estimated reliability is in accordance with the target value and the values obtained from the normal probabilistic based design. In this case the probability of ignition and flashover occurring are taken as given in the probabilistic model code [6]. Applying stochastic charring rates has an increasing influence on the probability of failure for a fire duration of approximately 30 minutes or more. In the case of shorter fire duration the influence is relatively small.

It should be emphasized that this example calculation involves a number of parameters and wood characteristics with distribution properties which are not fully known. The results should be considered as first estimates and the conclusions as indicative.

\section{References}

[1] ISO CW 4355 , Basis for design of structures - Determination of snow loads on roofs. 1991

[2] Perälä J., Reuna, R., (Regional and temporal variability of snow loads in Finland: in finnish) Lumen vesiarvon alueellinen ja ajallinen vaihtelu Suomessa. Vesi ja ympäristöhallitus. Julkaisuja - sarja A 56. Helsinki 1990.

[3] PrEN 1990 Eurocode - Basis of structural design - Final draft July 2001. Document CEN/TC 250/SC 5 : N 159.

[4] prEN 1995-1-1, Eurocode 5, Design of timber structures, Part 1-1, General Rules, General rules and rules for buildings, Final Draft, 2002-10-09.

[5] prEN 1995-1-2, Eurocode 5, Design of timber structures, Part 1-2, General - Struct. fire design, Final Draft, $2003-$ 08-12.

[6] Probabilistic Model Code. Joint Committee of Structural Safety, JCSS. 2001. http://www.jcss.ethz.ch.

[7] Puurakenteiden suunnitteluohjeet B10 (Finnish timber structures design codes, in finnish) RIL 120-2001. Helsinki 2001.

[8] Ranta-Maunus, A., Fonselius, M., Kurkela, J., Toratti, T., Reliability analysis of timber structures. Espoo 2001. Technical Research Centre of Finland. Research notes 2109. 102 p. + app. 3 p.

[9] Ranta-Maunus, A., Summary report of NI project on reliability of timber structures. October 2001. Joint Nordic wood project meeting and Cost E24 workshop. Copenhagen.

[10] SAKO 1999. Basis of design of Structures - Proposals for modification of partial safety factors in Eurocodes. Joint committee of NKB and INSTA-B. NKB Committee and work reports, 1999:01 E.

[11] Strurel, A structural Reliability Analysis Program System, COMREL \& SYSREL Users Manual, RCP GmbH, 1999. 
[12] Thelandersson, S., Larsen, H.J., Östlund, L., Isaksson, T., Svensson, S., Säkerhetsnivåer för trä och träproducter i konstruktioner. Lund Universität. Rapport TVBK-3039. 37 p. + app.

[13] Toratti, T., Ranta-Maunus, A., A discussion on the introduction of wood to the JCSS probabilistic model code. Cost E24. Probabilistic Modelling in Reliability Analysis of Timber Structures. Zurich, 10-11.10.2002.

[14] Personal communication with Jukka Hietaniemi VTT, Finland.

Acknowledgment This work was partially supported by bilateral Finish - Slovenian project (BI-FI/04-05-006). The support is gratefully acknowledged. 


\section{Appendix}

The required section height of the studied beam at the critical cross section based on Eurocode 5 and the Finnish building code B10 is as shown below. The beam was actually designed according to the Finnish building code and the actual height is $1060 \mathrm{~mm}$. The building does not actually have a 60 minute resistance requirement, but if this was the case, it would be fulfilled by the Finnish code but not by the Eurocode.

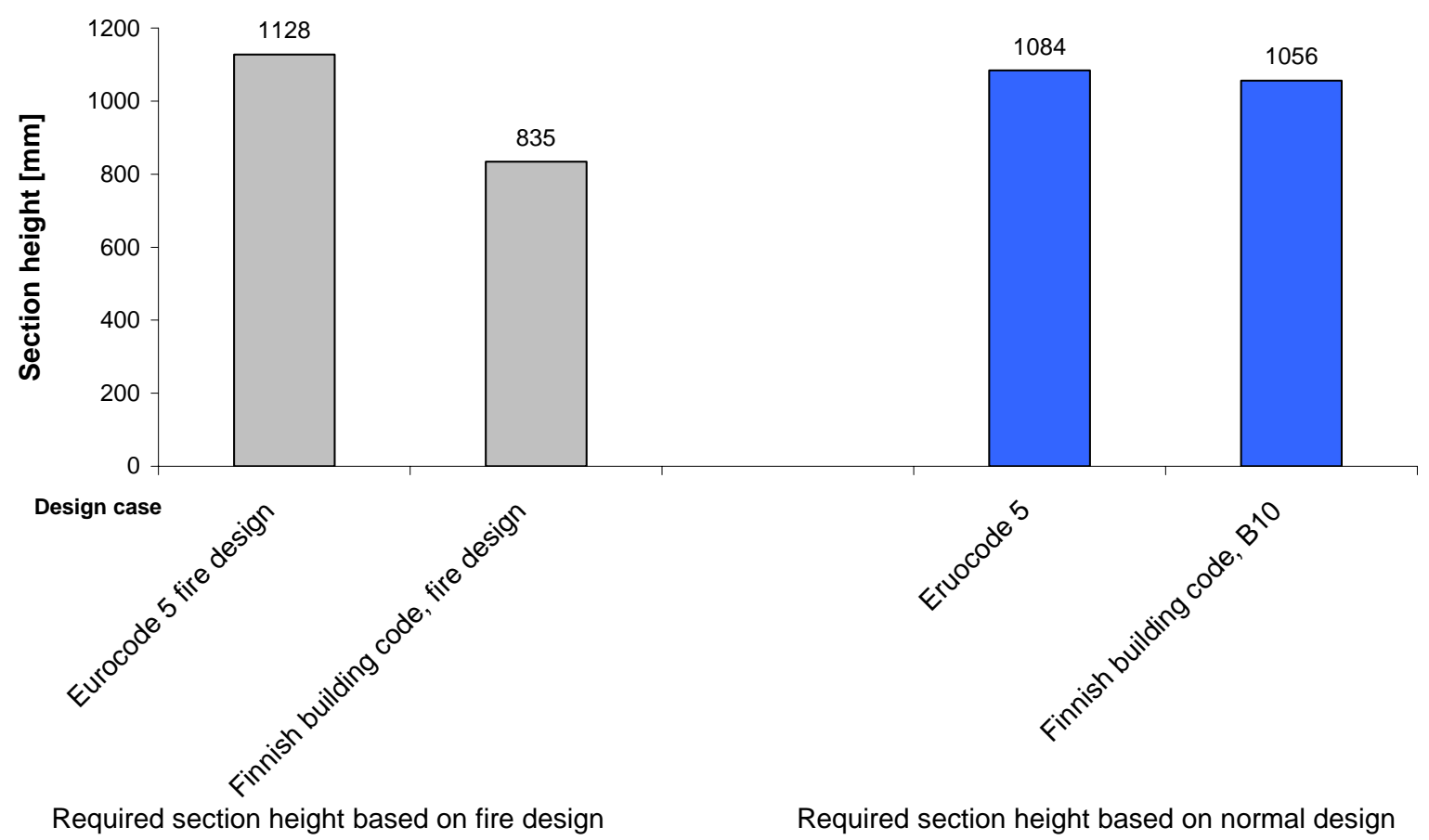

Figure 8. Required beams section heights based on deterministic code design. 